Southern Methodist University

SMU Scholar

Faculty Journal Articles and Book Chapters

Faculty Scholarship

2008

\title{
Codification of Late Roman Inheritance Law: Fideicommissa and the Theodosian Code
}

Joshua C. Tate

Southern Methodist University, Dedman School of Law

\section{Recommended Citation}

Joshua C. Tate, Codification of Late Roman Inheritance Law: Fideicommissa and the Theodosian Code, 76 Tijdschrift voor Rechtsgeschiedenis

This document is brought to you for free and open access by the Faculty Scholarship at SMU Scholar. It has been accepted for inclusion in Faculty Journal Articles and Book Chapters by an authorized administrator of SMU Scholar. For more information, please visit http://digitalrepository.smu.edu. 


\title{
Codification of late Roman inheritance law: fideicommissa and the Theodosian Code
}

\author{
Joshua C. Tate*
}

\begin{abstract}
Summary
It has long been known that most of the private law content of the Theodosian Code has not been preserved independently of the Lex Romana Visigothorum. Certain constitutions, not contained in the LRV but dating to the period covered by the CT, have survived in the Code of Justinian. This article discusses this problem with respect to a particular topic: fideicommissa. The article discusses whether a particular constitution, CJ 6.37.21, might have been included in the CT, either as part of a general rubric concerning inheritance or as part of a separate rubric on fideicommissa, and concludes by suggesting what the constitution might have looked like had it been under a separate heading.
\end{abstract}

\section{Keywords}

Fideicommissa, Theodosian Code, Lex Romana Visigothorum, Justinian

Judging by what survives of the Codex Theodosianus (CT), imperial legislation from Constantine to Justinian was marked by no special fondness for fideicommissa ${ }^{1}$. Of the eleven laws in Mommsen's edition of the $\mathrm{CT}^{2}$ that explicitly mention fideicommissa, at least seven involve extensive lists of various ways of acquiring property ${ }^{3}$. Three others are concerned specifically with secret fideicommissa and the procedure by which they are denounced to the government: in particular, a characteristically extreme law of Constantine declares that those who cheat a female heir through such devices are to be stripped of all their property and deported to an island ${ }^{4}$. Only one law in

\footnotetext{
* Assistant Professor of Law, Southern Methodist University, Dallas (Texas); Visiting Assistant Professor of Law, University of Pennsylvania, 3400 Chestnut St., Philadelphia, PA 19104, U.S.A.; jctate@smu.edu

1 D. Johnston, The Roman law of trusts, Oxford 1988, translates the Latin fideicommissum into English as 'trust'. However, the English and Roman legal institutions were not identical, and the translation may be somewhat misleading. Put simply, a fideicommissum is something that a testator asks someone benefiting from his / her will to do after his / her death. Fideicommissa that met certain requirements (on which see $i d$., p. 15) were actionable in classical and postclassical Roman law.

2 Mommsen's is the standard modern edition of the Codex Theodosianus.

3 See Johnston (supra, n. 1), p. 270-271. Fideicommissa are thus mentioned in passing in CT 8.18.5 (349); 3.8.2 (382); 12.1.107 (384); 16.5 .17 (389); 8.18.7 (395); 16.9.4 (417). CT 16.2.27 (390), regarding the property of deaconesses, includes a similar list, but also singles out secret fideicommissa in favor of clerics for special condemnation.

4 Constantine's harsh rule is contained in CT 10.11.1 (317). Other references to denuntiatio are found in CT 10.10.20 (392) and 2.4.6 (406).
} 
Mommsen's edition treats the fideicommissum as a valid and independent legal institution, and its attitude is somewhat less than enthusiastic. This law, CT 4.4.7 (424), attributed to Theodosius II, decrees that an unfinished will cannot be valid as a codicillary fideicommissum unless this is specified by the testator, and prohibits an action on the fideicommissum from being brought by an extraneous heir after an action on the inheritance has failed or vice versa'. A restrictive attitude toward fideicommissa could also be deduced from the fact that, unlike the Code of Justinian (CJ) ${ }^{6}$, Mommsen's reconstruction of the Theodosian Code does not contain a separate title ' $D e$ fideicommissis'.

The absence of an extant title on fideicommissa in the Theodosian Code is all the more striking in light of the attention given to them by the third-century rescripts apparently selected by Justinian from the earlier Diocletianic codes ${ }^{7}$. If the Theodosian Code was compiled 'ad similitudinem Gregoriani atque Hermogeniani codicis's, one might well wonder how a subject that seems to have been prominent in the latter could be almost ignored by the former. This discrepancy, of course, could simply be a function of the legal sources used by the different compilers. While the Diocletianic codes apparently contained nothing but private rescripts, these were excluded in favor of general edicts by Theodosius II ${ }^{9}$. It is quite conceivable that laws directed to public functionaries would mention fideicommissa far less frequently than responses to private individuals. One could, however, imagine a more ominous possibility: that the Theodosian compilers, for whatever reason, deliberately excluded certain laws having to do with fideicommissa. This explanation poses many problems, but it must be evaluated if we are to assess the development of inheritance law in the later Roman world.

When discussing the possible editorial practices of the Theodosian compilers, it cannot be emphasized enough that their Code does not survive intact. It has been estimated that we do not possess more than a third of the first five books of the Theodosian Code, and in a good many books entire rubrics may have been lost ${ }^{10}$. The standard modern edition of the Code, completed by Theodor Mommsen based on the preliminary work of Paul Krüger, is to be understood as a partial reconstruction rather than the actual Code as promulgated in $438^{11}$. Mommsen made use of numerous

${ }^{5}$ CT 4.4 .7 (424). Only heirs within the fourth degree of agnation or third degree of cognation may bring another action after the first has failed. T. Honoré, Some quaestors of the reign of Theodosius II, in: The Theodosian Code: Studies in the Imperial law of late antiquity, J. Harries and I. Wood eds., London 1993, p. 78-81.

${ }^{6}$ CJ 6.42 De fideicommissis, not surprisingly, deals with fideicommissa, although they are also discussed in other titles, e.g., 6.37 De legatis and 6.43 Communia de legatis et fideicommissis et de in rem missione tollenda.

$>$ CJ 6.42.1-29. On these earlier codes see S. Corcoran, The Empire of the Tetrarchs: Imperial pronouncements and government $A D$ 284-324, Oxford 1996, p. 25-42. It is not my purpose here to address the relationship between these pre-Theodosian codes and the Code of Justinian.

${ }^{8}$ CT 1.1.5 (429).

9 E. Volterra, Sul contenuto del Codice Teodosiano, Bullettino dell'Istituto di diritto romano, 84 (1981), p. 92-94.

${ }^{10}$ G. Rotondi, Studi sulle fonti del Codice Giustinianeo, in: Scritti giuridici I, Milan 1922, p. 212. There is good manuscript support for books $6-16$ of the Code, but not for books 1-5, which dealt with private law. See J.F. Matthews, Laying down the law: $A$ study of the Theodosian Code, New Haven 2000, p. 85-89.

"J. Gaudemet, La transmission des constitutions relatives au droit successoral au Bas-Empire et 
manuscripts in his edition, but his most important source for the sections dealing with testamentary succession was the Lex Romana Visigothorum, or 'Breviary of Alaric'. In Mommsen's edition, for example, title 4.4 De testamentis et codicillis is drawn in its entirety from the Breviary, since no independent manuscript of that section of the full Code was available. As is demonstrated by other titles for which we do possess an independent manuscript, however, the Breviary did not attempt to reproduce all, or even most of, the constitutions found in the Theodosian Code ${ }^{12}$. Of the ten original titles contained in CT 8.18 De maternis bonis, for example, the Visigoths only included $\operatorname{six}^{13}$, and only two of eight laws known to exist in CT 4.6 De naturalibus filiis were reproduced in the Breviary ${ }^{14}$.

It is quite possible, therefore, that some laws regarding fideicommissa were originally in the Theodosian Code but neglected by the Breviary. Given the heavy editorial hand of the Visigoths, moreover, one could even conceive of a lost CT rubric ' $D e$ fideicommissis' that has been excised by Alaric's compilers. The specter of a suppressed title stands in the way of any hasty claims regarding the attitude toward fideicommissa exhibited in the Theodosian Code.

Despite the fact that our knowledge of the Theodosian titles on inheritance is inevitably conditioned by the preferences of the Visigoths, the sixth-century Code of Justinian offers the possibility of filling in a few gaps. The preface to the first edition of Justinian's codification asserts that its aim was to edit the Theodosian Code and its two Diocletianic predecessors so that they might be combined with later constitutions in a fourth Code that would replace them all ${ }^{15}$. However much Tribonian and his assistants may have manipulated its contents, it seems undeniable that they had at their disposal a version of the Theodosian $\operatorname{Code}^{16}$ that was more complete than our own and relatively untouched by later editorial hands. By analyzing those constitutions in the CJ that are not found in Mommsen's edition of the CT, therefore, it might be possible to circumvent the effects of Visigothic editing.

Unfortunately, this method does not produce spectacular results. Of the laws in the Code of Justinian that belong to the period between Constantine and the compilation of the Theodosian Code and explicitly refer to fideicommissa, only three do not have a predecessor in Mommsen's reconstruction of the CT. One of them merely mentions fideicommissa along with various other ways of acquiring property, and thus adds little to what we know of the Theodosian Code ${ }^{17}$. The second is somewhat more interesting, but does not shed much light on the question at hand:

dans les royaumes barbares, Revue internationale des droits de l'antiquitée, 7 (1960), p. $401-$ 402.

12 Gaudemet (supra, n. 11), p. 433-434.

${ }_{13}$ CT 8.18.1, 2, 6, 7, 9, and 10 are reproduced in Brev. 8.9.1-6. CT 8.18.3-5 and 8 were not included.

${ }_{14}$ CT 4.6.4 and 4.6.8 are reproduced as Brev. 4.6.1-2; the others are not found in the Breviary.

15 C. Haec, pr.

${ }^{16}$ Apart from the imperial archives, where some copies of the Code must have been available, numerous private copies must have been made (see ]. Matthews, The making of the text, in: Harries and Wood (supra, n. 5), p. 19-20) for use not only in the law schools, but also in private practice. For the latter, see W. Turpin, The purpose of the Roman law codes, Zeitschrift der Savigny-Stiftung für Rechtsgeschichte, Romanistische Abteilung, 104 (1987), p. 620-623.

${ }_{17}$ CJ $6.23 .16(380)$. 
CJ 6.22.7 (Qui facere testamentum possunt vel non possunt):

Imppp. Valentinianus Valens et Gratianus $A A A$ ad Maximum. Cum heredes instituuntur imperator seu Augusta, ius commune cum ceteris habeant quod et in codicillis vel fideicommissariis epistulis iure scriptis observandum erit. et sicuti priscis legibus cautum est, imperatori quoque vel Augustae testamentum facere liceat et mutare.

D. VII id. Aug. Contionaci Gratiano A. II et Probo conss.

If this law was included in the full Theodosian Code, it is possible to guess why the Visigoths omitted it from their compilation, for its first provision, allowing emperors and empresses to acquire from codicils and fideicommissa, was at least partially repealed in $389^{18}$, and in any event there were no emperors or empresses in the Visigothic kingdom. Given that this law applies only to the specific case of dispositions in favor of the emperor or empress, it cannot serve as a suitable focal point for a discussion of fideicammissa and the Theodosian Code. For that, we must turn to the third law, which is notable for its wide applicability:

C] 6.37.21 (De legatis):

Imp. Constantinus $A$. ad populum. In legatis vel fideicommissis verborum necessaria non sit observantia, ita ut nihil prorsus intersit, quis talem voluntatem verborum casus exceperit aut quis loquendi usus effuderit.

D. k. Febr. Constantio II et Constante conss.

This constitution, like many others in the extant Theodosian Code ${ }^{19}$, treats legacies and fideicommissa together. It does so, however, with the intent, not of compiling a general list of methods of obtaining property after death, but of making a substantive point regarding the legal institutions themselves. Formal words are to be disregarded in favor of the testator's or settlor's intention: and thus the essential flexibility that is a hallmark of fideicommissa is affirmed even for legacies. Such a disposition, if part of the Theodosian Code, would refute any supposition of a consistent editorial bias against fideicommissa on the part of the Theodosian compilers.

CJ 6.37.21 will therefore serve as a suitable test case, not only for the issue of fideicommissa and the Theodosian Code, but also for the broader problem of the way in which the Code has been transmitted. By tracing the path of CJ 6.37.21 through the various late Roman law codes, we can begin to understand the implications of our dependence on the Breviary of Alaric for what we call the Theodosian Code. In this process three questions must be answered: (1) whether the content of CJ 6.37.21 as preserved in the Code of Justinian is derived from a genuine constitution belonging to the period covered by the Theodosian Code; (2) whether such a constitution could have been in the full CT, and (3) under which CT title or titles it might have been located.

${ }^{18}$ CT 4.4 .2 (389); cf. Symmachus ep. 2.13. The constitution of 389 states that emperors cannot take from 'codicils or letrers (codicillis aut epistulis)' and that property so bequeathed will pass instead to the children of the deceased. However, the constiturion qualifies this by saying that the emperor may still take from a lawfully written testament or nuncupation (testamenti vero scripturam legitimam vel nuncupationem). The constitution of 389 does not specifically mention fideicommissa, which may explain why CJ 6.22.7 survived.

19 See above. 
Although the constitution preserved in CJ 6.37.21 has attracted a great deal of discussion, few scholars have devoted much attention to its possible place in the Theodosian Code. Instead, historians have concentrated on the problem of its date, for while the inscription refers to Constantine, the consular year in the subscription (339) indicates the reign of his successor Constantius II. This difficulty is also posed by another law in the Code of Justinian that is unanimously regarded as connected with the fragment on fideicommissa and legacies contained in CJ 6.37.21 ${ }^{20}$ :

\begin{abstract}
C] 6.23 .15 (De testamentis: quemadmodum testamenta ordinantur):
Imp. Constantinus A. ad populum. Quoniam indignum est ob inanem observationem irritas fieri tabulas et iudicia mortuorum, placuit ademptis his, quorum imaginarius usus est, institutioni heredis verborum non esse necessarium observantiam, utrum imperativis et directis verbis fiat an inflexa. Nec enim interest, si dicatur 'heredem facio' vel 'instituo' vel 'volo' vel 'mando' vel 'cupio' vel 'esto' vel 'erit', sed quibuslibet confecta sententiis, quolibet loquendi genere formata institutio valeat, si modo per eam liquebit voluntatis intentio, nec necessaria sint momenta verborum, quae forte seminecis et balbutiens lingua profudit. Et in postremis ergo iudiciis ordinandis amota erit sollemnium sermonum necessitas, ut, qui facultates proprias cupiunt ordinare, in quacumque instrumenti materia conscribere et quibuscumque verbis uti liberam habeant facultatem.

S. d. k. Febr. Serdiceae Constantio A. et Constante C. conss.
\end{abstract}

The affinity of these two fragments is obvious: apart from the almost identical inscriptions and subscriptions, they both remove the necessity for formal words (necessaria ... uerborum) in various dispositions mortis causa. For over a century, however, a controversy has persisted regarding whether they are to be joined with other fragments contained in the CJ and CT of a general edict issued by Constantine ad populum in 320 or 326 , or simply dated to 339 and attributed to his son ${ }^{21}$. Both explanations are palaeographically conceivable: while Constantinus might at first seem a simple error for Constantius, it is equally likely that the consular dates have been transmitted incorrectly, especially given the use of abbreviations ${ }^{22}$. Albanese, moreover,

${ }^{20}$ See B. Albanese, L'abolizione postclassica delle forme solemni nei negozi testamentari, in: Sodalitas, Scritti in onore di Antonio Guarino II, Naples 1984, p. 779-780.

${ }_{21}$ The attribution of CJ 6.23.15 and 6.37.21 to Constantine was proposed by O. Seeck, Regesten der Kaiser und Päpste, Stuttgart 1919, p. 59 and 169, who includes the two fragments in his Regesten for the year 320, along with CT 8.16.1 (CJ 8.57.1), CT 3.2.1 (CJ 8.34.3), CT 4.12.3, and CT 11.7.3 (CJ 10.19.2). These fragments deal respectively with the annulment of penalties for celibacy and childlessness (CT 8.16.1), the annulment of provisions for forfeiture (CT 3.2.1), freeborn women who cohabit with fiscal slaves (CT 4.12.3), and the collection of taxes (CT 11.7.3). With the exception of CT 4.12.3, all of them adopt a tone of abolishing harsh or outdated legal rules and procedures in order to benefit the populace: an attitude also exhibited in CJ 6.23.15 and 6.37.21. CT 4.12.3 is also unusual in that Seeck has adopted an alternate manuscript reading (the Mommsen edition has 'dat. VI kal. Sept.') in order to bring it into line with the dates of 31 January or 1 February given for the other fragments. Not surprisingly, Albanese (supra, n. 20), p. $782 \mathrm{n} .16$, has suggested that CT 4.12 .3 does not originate from the same edict as the rest. Seeck's inclusion of CT 4.12.3 has been upheld, however, by J. Evans-Grubbs, Law and family in Late Antiquity: the Emperor Constantine's marriage legislation, Oxford 1995, p. 120. The question whether this edict was issued in 320 or 326 remains in dispute: while Seeck decided in favor of the former, following CT 8.16.1 and 11.7.3, Albanese (supra, n. 20), p. 784-785, leaves open the possibility of 326 offered by CT 3.2.1. Matthews, Laying down (supra, n. 10), p. 237-239, argues that the evidence from imperial nomenclature and place of issue is inconclusive.

${ }_{22}$ This problem is especially serious with regard to Constantine's reign: see Evans-Grubbs (supra, n. 21), p. 51-52. 
has argued convincingly for the latter interpretation, citing a passage from Eusebius's Life of Constantine in support of his case ${ }^{23}$. The law should therefore be referred to as Constantinian in the dynastic rather than the individual sense ${ }^{24}$.

For present purposes, the question of which emperor issued these fragments is insignificant in comparison with the possibility of Justinianic interpolation. No one would dispute the fact that Justinian's commission edited, rearranged, and reworded the constitutions found in his Code, or that some provisions that were obsolete were excluded. With regard to CJ 6.37.21, it cannot be denied that a law issued by Justinian's chancellery in 531 had affirmed that formal words were unnecessary in legacies and fideicommiss $a^{25}$, and the complete fusion of the two institutions is rightly attributed to the Justinianic period ${ }^{26}$. Yet it is revealing to observe the account of events given in the Institutes:

\section{Inst. 2.20.1-2 (De legatis):}

... Legatum itaque est donatio quaedam a defuncto relicta. Sed olim quidem erant legatorum genera quattuor: per vindicationem, per damnationem, sinendi modo, per praeceptionem: et certa quaedam verba cuique generi legatorum adsignata erant, per quae singula genera legatorum significabantur. Sed ex constitutionibus divorum principum sollemnitas huiusmodi

${ }^{23}$ Albanese (supra, n. 20), p. 785-787. The passage of Eusebius in question may be translated as follows: '(De Vita Constantini 4.26) ... And then, similarly, as regards people leaving life, the ancient laws had determined that even in the last breath it was necessary for wills being set in order to be dictated precisely with (specific) expressions of words and for specific methods and words of a certain kind to be selected. And many bad things were done because of this against the spirit of what the deceased had intended. Therefore, looking at these things together, the emperor also altered this law, saying that the dying man should arrange things according to his desire, with plain language and in the manner of speaking to which he was accustomed, and set out his intention in whatever writing chanced to occur, and even, if he wished, without writing, provided that he did this with witnesses present who were competent to guard the pledge with honesty'.

The close parallels between Eusebius's account and CJ 6.23.15 have been admitted even by Sargenti, who leans toward the attribution to Constantius. M. Sargenti, Il diritto privato nella legislazione di Costantino, in: Atti del Accademia Romanistica Costantiniana, $\mathrm{I}^{\circ}$ Convegno internazionale, [Perugia 1975], p. 229-332, esp. p. 297-298. Given that Eusebius probably died on 30 May 339, moreover, as explained by T. Barnes, Constantine and Eusebius, Cambridge, Mass. 1981, p. 263, it seems unlikely that he would have mistakenly attributed to Constantine a law issued by the reigning emperor Constantius only four months previously. The evidence of Eusebius is corroborated by the habitual issuance of laws at Serdica by Constantine as well as his penchant for addressing edicts ad populum, neither of which are frequently attested for Constantius, and by a possible reference in CT 4.4 .3 (396?), as Albanese demonstrates (supra, n. 20), p. 782-783 n. 17 and p. 787. Constantius still has his defenders, such as Sargenti (supra), p. 297 and 308-309, but no convincing case has been made in his favor. This conclusion seems to have been reached by Voci, who has recently abandoned his former position in favor of an attribution to Constantine. Compare P. Voci, Diritto ereditario romano, II, Milan 1963, p. 129 and 234, with P. Voci, Il diritto ereditario romano nell'età del tardo impero, I: Le costituzioni del IV secolo, in: Studi di diritto romano, II, Milan 1985, p. 95-96. Matthews, Laying down (supra, n. 10), p. 239 , is in accord.

${ }^{24}$ M. Amelotti, Il testamento romano attraverso la prassi documentale, I, Florence 1966, p. 249, rightly points out that it makes little difference whether the law is artributed to Constantine or his son unless the intent is to suggest that the emperor was personally involved in the legislative process.

${ }_{25}$ CJ 6.43.2. Cf. CJ 6.43.1 (529), which established a uniform procedural regime for all legacies and fideicommissa.

${ }^{26}$ Johnston (supra, n.1), p. 287-288. 
verborum penitus sublata est. nostra autem constitutio ${ }^{27}$, quam cum magna fecimus lucubratione, defunctorum voluntates validiores esse cupientes et non verbis, sed voluntatibus eorum faventes, disposuit, ut omnibus legatis una sit natura et, quibuscumque verbis aliquid derelictum sit, liceat legatariis id persequi non solum per actiones personales, sed etiam per in rem et per hypothecariam: cuius constitutionis perpensum modum ex ipsius tenore perfectissime accipere possible est ... ${ }^{28}$.

It is clear that the author of this passage (who, at least formally, is Justinian himself) has no interest in downplaying Justinian's achievements. Rather than give Justinian all the credit for reforming the ancient laws, however, the author refers to 'constitutiones diuorum principum' by which the use of formal words in legacies 'penitus sublata est'. Krüger, in his edition of the Institutes, took this to include CJ 6.37.21, and his suggestion seems eminently plausible ${ }^{29}$. The passage makes it quite clear that formal words in legacies were already unnecessary by 529 , when real and hypothecary actions were extended to all legatees. The essence of the Justinianic reform as described in the Institutes, therefore, lay not in abolishing formal words, but in establishing a uniform procedural regime for both fideicommissa and legacies. In general, it has been argued that Justinian's compilers were not given the power to create new substantive ${ }^{l a w^{30}}$, and one should certainly be cautious about suggesting interpolations when there is no good reason to do so. In the absence of a compelling reason to believe otherwise, we must accept that the points of substantive law presented in CJ 6.37.21 did not originate with Justinian ${ }^{31}$.

27 CJ 6.43 .1 (529).

28 The Institutes goes on to discuss CJ 6.43 .2 (531), in which all distinctions between fideicommissa and legacies were completely abolished.

29 The use of the plural 'constitutionibus' is puzzling, but may be an allusion to the senatusconsultum Neronianum, which apparently confirmed legacies 'quac uerborum uitio iure ciuili non ualent' (Sabinus, quoted in Gai. Inst. 2.218). Although not technically a constitutio principis, the s.c. Neronianum seems the most likely explanation, since the reference to legacies in Nov. Theod. 16 (439) was not reproduced in Justinian's Code, as pointed out by Albanese (supra, n. 20), p. 791 n. 27.

${ }_{30}$ A. Watson, Prolegomena to establishing pre-Justinianic texts, Tijdschrift voor Rechtsgeschiedenis, 62 (1994), p. 116.

31 The only scholar who has recently proposed a possible interpolation in CJ 6.37.21 is Clemence Dupont, though the object of her scalpel is not, interestingly enough, that which concerns legacies, but rather the phrase 'uel fideicommissis'. C. Dupont, Les successions dans les constitutions de Constantin, IVRA, 15 (1964), p. 62. Arguing that formal words had never been necessary in fideicommissa, Dupont claims that Constantine would have had no motive to mention them: thus Tribonian and his men 'ont sans doute procédé distraitement à l'interpolation, sans apercevoir son inutilité. The suggestion that Justinian's compilers were prone to 'absent-minded' interpolation is unsettling. It seems far more likely that the prevailing tendency in dealing with such a large body of law would be to cut things out rather than insert new phrases when none were required. More importantly, although the use of formal words in fideicommissa was clearly unnecessary by the time of Justinian, it is possible that clarification on this point was still needed in Constantine's day. If fideicommissa were in fact understood from the beginning to be free of form, the frequent examples in the sources of acceptable wordings are difficult to explain. See Johnston, op. cit. (supra, n. 1), p. 155-156. The following passage from the Sententiae Pauli, for example, suggests that some confusion regarding this point still persisted in the fourth century: PS 4.1.6:

'Fideicommittere his uerbis possumus ROGO PETO VOLO MANDO DEPRECOR CUPIO INIUNGO. DESIDERO quoque et IMPERO uerba utile faciunt fideicommissum. RELINQUO uero et COMMENDO nullam fideicommissi pariunt actionem'.

As pointed out by Johnston, p. 163-164, this list seems to present three categories: words that have always been acceptable, words that were for some reason considered marginal but are now 
Of course, just because Justinian's compilers did not disguise their own reforms as Constantinian law, it does not follow that his Code reproduced the entire constitution as originally issued. One cause for suspicion is immediately apparent: while CJ 6.23.15pr.-1. refers specifically to the heredis institutio, CJ 6.23.15.2 speaks of all testamentary instruments (quacumque instrumenti materia). This has led Albanese to suggest that the fragment preserved in CJ 6.37.21 was inserted just before CJ 6.23.15.2 in the original edict ${ }^{32}$. Such manipulation is typical of both the Theodosian and the Justinianic compilers, who as a matter of course divided original constitutions into fragments ${ }^{33}$.

More elusive, however, is the question what has been omitted from the original sanction. Voci has suggested several provisions, including the requirements that a sufficient number of witnesses be present, that the testament be qualified as such from the outset, and that the contents be disclosed ${ }^{34}$. All of these possibilities seem reasonable, but for the first we happen to have corroborating evidence, provided that one does not attribute this legislation to Constantius. Eusebius, in describing an edict of Constantine that Albanese and others have identified with CJ 6.23.15 and 6.37 .21 , mentions the presence of 'witnesses . . . who were competent to guard

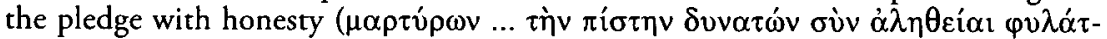
$\tau \varepsilon \imath v)^{\prime}$ as a requirement the emperor included in his law. It would certainly be misguided to attribute anything resembling legal precision to Eusebius's account $t^{35}$, and his tendency to exaggerate the supposedly Christian achievements of Constantine is obvious. Yet there is no reason to reject his account out of hand. If Constantine did demand the presence of witnesses in his law, moreover, one can suggest why the provision could have been omitted by Justinian's compilers as redundant, since other constitutions in their Code discuss this requirement in greater detail ${ }^{36}$.

Without making any definite claims, one can easily accept that CJ 6.23.15 and 6.37.21 probably had more to say about dispositions mortis causa than Justinian's commission preferred to include. Nevertheless, the first question posed above has been answered in the affirmative. Although many things in the original constitution

acceptable, and unacceptable words. Given that some doubr may have persisted regarding such words as 'desidero' and 'impero', there would have been good reason for Constantine to affirm once and for all that the observance of formal words was unnecessary in fideicommissa. The burden of proof thus rests on those who wish to suggest a Justinianic interpolation, and the argument suggested by Dupont does not meet the challenge.

${ }_{32}$ Albanese (supra, n. 20), p. 789-790.

33 E. Volterra, Il problema del testo delle costituzioni imperiali, in: La critica del testo, Florence 1971, p. 1094-1095.

34 Voci, Il diritto (supra, n. 23), p. 97-98. These last two suggested provisions are partially based on the claim that they were repealed by Arcadius in CT 4.4.3 (396?), a questionable argument given that Arcadius refers to a 'diui Constantini sanctionem' along with other precedents. Voci corroborates his assertion, however, by citing parallel requirements in Constantinian laws regarding donation and sale. Less convincing is the proposed reference to the fact that an heir could not be instituted in codicils, resting solely on the later proclamation of this in CJ 6.36 .7 (332).

${ }^{35}$ Sozomen, who had been a professional advocate, might be more reliable in this regard, see J. Harries, Sozomen and Eusebius: the lauyer as church historian in the fifth century, in: The inheritance of historiography 350-900, C. Holdsworth and T.P. Wiseman eds., Exeter 1986, p. 47-48, but there is no mention of CJ 6.23.15 or 6.37.21 in his Ecclesiastical History.

${ }^{36}$ For testaments, the requirement is mentioned in CJ 6.23 .12 (293), among other laws. Its omission from CJ 6.37 .21 may be explained by CJ 6.42 .32 (531), in which Justinian waived the need for witnesses in fideicommissa when the beneficiary is willing to undergo an oath concerning calumny (cf. Inst. 2.23.12). 
may have been excised or rearranged, the essential content of CJ 6.37 .21 and its counterpart almost certainly belongs to the period covered by the CT. We must now turn to the second question: whether some version of CJ 6.23.15 and 6.37.21 was contained in the full Theodosian Code.

As pointed out by Rotondi, the evidence weighs heavily against any use by Justinian of material belonging to the period covered by the Theodosian Code, but not contained therein ${ }^{37}$. Not only do both of the laws authorizing the Theodosian compilation order all constitutions from Constantine onward to be collected ${ }^{38}$, but the second also declares that no constitution not contained in the Code may thereafter be cited in court $^{39}$. Such a combination of inclusiveness and exclusiveness means that few constitutions are likely to have survived independently over the next hundred years ${ }^{40}$. Moreover, Justinian's compilers were explicitly directed to select constitutions from the three earlier codes ${ }^{41}$, which would seem to rule out the inclusion of constitutions dating from the period covered by the Theodosian Code but not contained therein. To conclude that CJ 6.23.15 and 6.37.21 were not in the Theodosian Code, one would have to assume not only that Justinian's compilers had access to constitutions preserved in the law schools or central imperial archives that were omitted from the Theodosian Code ${ }^{42}$ yet somehow survived the promulgation of that Code, but also that Justinian's compilers decided to include these constitutions notwithstanding their instructions from the emperor.

Seizing upon this unlikely possibility, Gaudemet attempted to employ certain fragments in the Code of Justinian as evidence in favor of an exclusive editorial policy on the part of the Theodosian compilers. Examining the laws contained in the surviving CT title De testamentis et codicillis, Gaudemet concluded that the compilers 'show themselves to be demanding' regarding formal requirements ${ }^{43}$. This was then contrasted with the Code of Justinian, which includes fragments such as CJ 6.23.15 and 6.37.21

37 Rotondi (supra, n. 10), p. 211-219.

38 CT $1.1 .5(429)$ and $6(435)$.

${ }^{39}$ CT 1.1.6.3 (435), repeated in Nov. Theod. 1.6 (438). See A.J.B. Sirks, The Theodosian Code: A study, Friedrichsdorf 2007, p. 201.

40 Regarding their fate immediately after the promulgation of the Code, Harries (supra, n. 35), p. 48, suggests that Sozomen may have made use of legal sources not contained in the Theodosian Code for his Ecclesiastical History, written in Constantinople during the $440 \mathrm{~s}$. This remains conjectural, however, and in any event does not indicate that any such constitutions remained available for consultation during the reign of Justinian.

41 C. Haec, pr.

${ }^{42}$ The likelihood of this possibility depends on the sources used by the Theodosian compilers. According to A.H.M. Jones, The Later Roman Empire 284-602: A social economic and administrative survey, Oxford 1964, T. Honoré, The making of the Theodosian Code, Zeitschrift der SavignyStiftung für Rechtsgeschichte: Romanistische Abteilung, 103 (1986), p. 161-162, Matthews, The making (supra, n. 16), p. 41, and others, the sorry state of central archives forced the Theodosian commission to make extensive use of scattered provincial sources. This would imply that few constitutions not in the Theodosian Code would have been available in Constantinople for consultation by Justinian's compilers a century later. A.J.B. Sirks, however, assigns a more prominent role to central imperial archives. Sirks (supra, n. 39), p. 151-152; B. Sirks, The sources of the code, in: Harries and Wood (supra, n. 5), p. 49-52. Even the theory proposed by Sirks, however, does not imply that there was any reason why Justinian's commission would have bothered to make use of extraneous material when they had the full CT at their disposal and were directed to use it.

43 'Pour y atteindre les compilateurs se sont montrés exigeants sur les formes'; Gaudemet (supra, n. 11), p. 429. 
that are more liberal in this regard ${ }^{44}$. While acknowledging that the absence of these constitutions in our edition of the CT may be a result of Visigothic editing, Gaudemet was nonetheless inclined to attribute the omissions to the Theodosian compilers ${ }^{45}$.

The supposed trend discerned by Gaudemet in the surviving Theodosian Code, however, does not provide a convincing motive for the exclusion of CJ 6.37.21 and its counterpart. First, it is not clear that CJ 6.23 .15 and 6.37 .21 would really have been that much out of place in Theodosian Code ${ }^{46}$. Second, we have evidence suggesting that they were indeed included. In a Novel of 446, Valentinian III refers to the 'decisions of those emperors who with greater prudence in their own sanctions removed the ambiguities of the ancient law (uetusti iuris ambages)', proclaiming that one can now dictate a last judgment 'quoquomodo et quibuscumque uerbis's7. If the 'decisions' alluded to include CJ 6.23.15, as seems likely ${ }^{48}$, then in order to maintain its exclusion from the Theodosian Code one must suppose that the Western emperor and his consistory obtained a separate copy from another source ${ }^{49}$. It is much easier to believe that Valentinian's law is referring to the contents of the full Theodosian Code, and that any alleged hostility to verbal formalism on the part of the Theodosian compilers is an illusion. All things taken into consideration, therefore, it seems almost certain that both CJ 6.23.15 and 6.37.21 were once in the Theodosian Code.

44 Gaudemet (supra, n. 11), p. 431-434.

45 'On serait cependant enclin à attribuer ces omissions aux rédacteurs du Code Théodosien, car elles témoignent de ce souci d'écarter un trop grand libéralisme dans l'appréciation des dispositions de dernière volonté que l'on retrouve dans le choix des texts qu'ils ont fait figurer au Code'; Gaudemet (supra, n. 11), p. 434.

${ }_{46}$ This is the conclusion reached by Matthews, Laying down (supra, n. 10), p. 236. CT 4.4.1 (326) and CT 4.4.4 (397), for example, do not reflect a hostile attitude to verbal formalism so much as a demand that testamentary dispositions be properly witnessed and recorded. This is also true of the final clause in CT 4.4 .7 (424), although the constitution as a whole is more complicated, as discussed above. As Johnston (supra, n. 1), p. 147, has argued, verbal informality and evidentiary strictness tend to go hand in hand: "the fewer the formal acts and declarations required, the greater the need for informal acts to be properly attested'. It is quite possible, as mentioned above, that the original Constantinian edict also required the presence of witnesses, and thus CJ 6.23.15 and 6.37.21 need not have differed from other CT titles in this regard. Two other laws cited by Gaudemet (CT 4.4 .2 (389), on codicils and fideicommissa; CT 4.4 .5 (416) on unwritten declarations), moreover, are specifically concerned with dispositions that benefit the emperor and his relatives. Most importantly, there exists one constitution in the surviving Theodosian Code that even Gaudemet acknowledged to be 'liberal', for it specifies that superfluous things written in a testament do not make it invalid. CT 4.4 .3 (396?); cf. Gaudemet (supra, n. 11), p. 429 n. 51 .

47 Nov. Val. $21.1 .3(446)$.

48 The words 'quibuscumque uerbis' are found in CJ 6.23.15, and the removal of 'uetusti iuris ambages' sums up the spirit of the Constantinian legislation. The other 'decision' referred to is almost undoubtedly CJ 6.23 .19 (413), likewise excluded from the Mommsen edition of the Theodosian Code. The reference to 'quibuscumque uerbis', however, is not found in what survives of Honorius's law, and may therefore derive from CJ 6.23.15. The use of the plural 'declarant' in Nov. Val. 21.1.3 (446) suggests that this is correct.

49 Given that the bureaucratic center of the empire was located in the East, along with the major law schools, it is by no means clear how an independent copy of an edict issued over a century before could have been easily procured in Rome, let alone why anyone would have bothered to do so. The predominance of Western legislation in the CT does not imply Western archival or administrative efficiency, since these constitutions could easily have been taken from collections made by lawyers and interested private individuals. See Matthews, The making (supra, n. 16), p. 43. 
Assuming that these constitutions were in the Theodosian Code, it remains finally to consider where in the Code they might have been located. One possibility, followed by Krüger in his unfinished reconstruction of the Code ${ }^{50}$, is that both fragments were included, either together or separately, under the existing CT rubric 'De testamentis et codicillis'. This would imply that the isolation of the fragment regarding fideicommissa and legacies under a separate title was the work of the Justinianic compilers. A second possibility, however, is that Justinian merely followed the pre-existing arrangement of the Theodosian Code. This would give us a separate, lost CT rubric not found in Mommsen's edition, called either 'De legatis' or 'De legatis et fideicommissis's1. Yet one can even conceive of a third scenario: that the contents of $\mathrm{CJ} 6.37 .21$ were split between two rubrics of the CT, with the reference to legacies combined with the fragment now preserved in CJ 6.23.15 under CT 4.4 De testamentis et codicillis and a separate fragment presented under a lost CT title De fideicommissis. The latter fragment might look something like this:

... In fideicommissis uerborum necessaria non sit obseruantia, ita ut nihil prorsus intersit, quis talem uoluntatem uerborum casus exceperit aut quis loquendi usus effuderit ... .

This reconstruction is, of course, wholly conjectural, but it is supported by a tendency in late postclassical law to treat fideicommissa as a 'type of succession which rivals succession by will' 52 .

Confronted with such an arrangement in the CT, Justinian's commissioners could have moved the reference to legacies to $C J$ 6.37.21 and relocated the hybrid constitution under the rubric 'De legatis', in keeping with the new procedural equivalence of the two institutions. Given that flexibility in operative language was a hallmark of fudeicommissa even in the classical period ${ }^{53}$, however, it is not clear why the CT compilers would need to reemphasize the relatively informal nature of fideicommissa by isolating the fragment on fideicommissa from the Constantinian reform as a whole. Thus, while a separate CT title De fideicommissis can be imagined, the CJ evidence in its favor is not particularly strong - but neither does the CJ give us any reason to assume that no such separate title existed. Until more compelling evidence is adduced, the third question suggested at the beginning must remain unanswered.

The probable inclusion of the fragment preserved in CJ 6.37.21 in the full Theodosian Code indicates that any apparent lack of attention to fideicommissa is not to be blamed on the editorial practices of the compilers. Nevertheless, even if one could be led to accept CJ 6.37.21 as the basis for a suppressed rubric 'De fideicommissis' in the Theodosian Code, nothing in the above analysis has seriously challenged the notion that the Theodosian constitutions simply had less to say about civil-law institutions such as fideicommissa than their counterparts in the Diocletianic codes. Yet the Code

so P. Krüger ed., Theodosiani Fasciculus I, Berlin 1923, p. 126-27.

51 The second possibility would imply that Justinian has divided the original CT title De legatis into two, one 'De legatis' and another 'De fideicommissis'.

52 Johnston (supra, n. 1), p. 150. Of the examples cited by Johnston that demonstrate this tendency, CT 16.9.4 (417) and CT 4.4.7 (424) are the latest as well as the most clear. All of the constitutions that seem to associate fideicommissa with legacies are earlier: CT 8.18.5 (349); 3.8.2pr (381); 12.1.107 (384). The evidence is scanty, but suggests a gradual isolation of fideicommissa from legacies over time.

53 See, e.g., G. 2.281; Johnston (supra, n. 1), p. 155-169. 
of Justinian cannot be relied upon to correct all the omissions of the Visigoths, and it is quite possible that more constitutions regarding fideicommissa and other aspects of inheritance law have been irrevocably lost. CJ 6.37.21 should serve to caution historians who seek to judge the Theodosian Code according to its surviving contents. If we do not attempt to take into account the omissions of the Breviary, we are likely to mistake Alaric's codification for that of Theodosius ${ }^{54}$.

54 I would like to thank Lisa Hasday, Tony Honoré, David Johnston, Rolf Knütel, and Boudewijn Sirks for their comments on this article. This research was made possible in part by a generous grant from the Emily Parker Endowed Faculty Research Fund at SMU Dedman School of Law. 